\title{
REGIONAL EARNING PATTERNS: NOTE
}

\author{
Edward Nissan
}

\section{Introduction}

A noticeable feature of the U.S. economy in recent years has been the shift in employment and population among regions. The underlying causes may be attributed to many factors operating individually or in combination. These factors include changes in demand for certain manufacturing and agricultural products, energy resources, and services, in domestic as well as international markets. The introduction of new technologies tends to favor location of economic activity in some regions rather than in others. Furthermore, government expenditures and taxes have differential regional impacts.

These changes influence the reallocation of employment and population, and of total regional income and earnings (the sum of wages and salaries, other labor income and of proprietors' income). A booming region registers a higher growth in earning than an economically stagnant region (Garnick 1984, 1985, 1986). Garnick was concerned with the differentials in growth rates of population, total income and earnings in MSA and nonMSA that typify urbanized and less-urbanized regions. The time period of his study 1959 to 1984 , was disaggregated into three segments - 1959-69, 1969-79, and 1979-84.

The purpose of this study is to present a supplementary examination of the findings of Garnick using a portion of his 1986 data. The concern here, however, pertains to regional differentials in total income and earnings in MSA areas across the three time segments and four city sizes.

A summary of the data used herein is reported in Table 1. The values shown for the eight regions defined by the Bureau of Economic Analysis (see Endnotes) are the average growth rates for the cities of the four sizes that comprise the MSAs. The fourcity size groups are less than 0.5 million, 0.5 -to 1 million, 1 to 2 million, and over 2 million. Growth rates are indicated in Table 1 for personal income in column one, earnings in column two, and earnings excluding farming and manufacturing in columns three through five. Earnings excluding farming and manufacturing factor out the impact of these sectors on total earnings.

"Professor of Economics, University of Southem Mississippi

\section{Model Background}

Three components of the model are associated with the growth of total income and earnings: Region $(R=$ $1,2, \ldots, 8)$, Time $(T=1,2,3)$ and MSA size $(M=1,2, \ldots, 4)$. Three-way analysis of variance was used to test the potential effect of each factor on growth. There are three tests to establish significance.

The results of the tests indicate that the Region (R) and Time (T) variables are significant in explaining the variation in growth while MSA size is not. A two way analysis of variance was used as an additional test of the significant variables. Hypothesis 1 states that the growth rate is determined primarily by regional variation. Hypothesis 2 asserts that differences are determined primarily by time variation. To determine whether these variables are interdependent, an interaction component (RXT) was assumed. If there is no interaction between the two variables, the presence of one will not influence the other.

Table 2 provides a summary of the results. The factors under consideration are significant in all cases as indicated by observing the values of the F-ratios and comparing them with the theoretical F-distribution with the appropriate degrees of freedom. These are: $F(0.01 ; 7,69)$ equals $2.91 ; F(0.01 ; 2,69)$ equals 4.92 ; and $F(0.01 ; 14,69)$ equals 2.35 , where 0.01 is the significance level of the test and the two succeeding numbers are the degrees of freedom.

A conclusion can be drawn by observing theF-ratios in Table 2, that time is the more important variable. The influence of time regional differentials in growth rates is very evident. For hypothesis testing, a significant F-test implies the rejection of equality of regional growth rates over time. A third analysis was undertaken to identify groups of regions that do not differ significantly. A multiple comparison procedure was used to compare all possible pairs of growth rates. Pairs that do not differ significantly were grouped in identifiable subsets. The results and analysis follow in the next section.

\section{Empirical Results}

Several procedures are available for examining the homogeneity of growth rates. The method used here is due to Newman and Keuls (Ostle and Malone, 1988, p. 189). 
Table 1

Average Rate of Growth of Total Personal Income and Earnings, by Regions of the United States, 1959-1984

(1)

\begin{tabular}{|c|c|c|c|c|c|}
\hline \multirow[b]{2}{*}{ Region } & \multirow{2}{*}{$\begin{array}{l}\text { (1) } \\
\text { Personal } \\
\text { Income } \\
\text { (percent) }\end{array}$} & \multirow{2}{*}{$\begin{array}{c}\text { (2) } \\
\text { Total } \\
\text { Earnings } \\
\text { (percent) }\end{array}$} & \multicolumn{3}{|c|}{$\begin{array}{l}\text { (4) } \\
\text { Earnings Excluding }\end{array}$} \\
\hline & & & $\begin{array}{l}\text { Farming } \\
\text { (percent) }\end{array}$ & $\begin{array}{c}\text { Mfg. } \\
\text { (percent) }\end{array}$ & $\begin{array}{l}\text { Mfg. \& } \\
\text { Farming } \\
\text { (percent) }\end{array}$ \\
\hline \multicolumn{6}{|c|}{$\underline{1959-69}$} \\
\hline New England & 6.90 & 6.71 & 6.76 & 7.30 & 7.39 \\
\hline Mideast & 6.48 & 6.20 & 6.25 & 6.68 & 6.77 \\
\hline Great Lakes & 6.47 & 6.43 & 6.47 & 6.82 & 6.91 \\
\hline Plains & 6.55 & 6.39 & 6.55 & 6.66 & 6.71 \\
\hline Southeast & 8.24 & 8.20 & 8.34 & 8.16 & 8.33 \\
\hline Southwest & 7.86 & 7.73 & 7.87 & 7.48 & 7.67 \\
\hline Rocky Mountain & 7.05 & 7.02 & 7.05 & 7.13 & 7.16 \\
\hline Far West & 7.60 & 7.24 & 7.59 & 7.39 & 7.82 \\
\hline \multicolumn{6}{|c|}{$\underline{1969-79}$} \\
\hline New England & 8.79 & 8.30 & 8.32 & 8.78 & 8.83 \\
\hline Mideast & 8.43 & 7.82 & 7.85 & 8.38 & 8.43 \\
\hline Great Lakes & 8.97 & 8.42 & 8.43 & 8.87 & 8.89 \\
\hline Plains & 9.77 & 9.54 & 9.61 & 9.89 & 9.99 \\
\hline Southeast & 11.39 & 10.71 & 10.75 & 11.04 & 11.08 \\
\hline Southwest & 12.71 & 12.38 & 12.39 & 12.61 & 12.63 \\
\hline Rocky Mountain & 12.53 & 12.30 & 12.40 & 12.19 & 12.30 \\
\hline Far West & 11.31 & 10.54 & 10.54 & 10.76 & 10.76 \\
\hline \multicolumn{6}{|c|}{$\underline{1979-84}$} \\
\hline New England & 10.48 & 9.83 & 9.84 & 10.62 & 10.64 \\
\hline Mideast & 9.10 & 7.91 & 8.10 & 9.24 & 9.30 \\
\hline Great Lakes & 6.97 & 5.17 & 5.21 & 6.53 & 6.61 \\
\hline Plains & 8.62 & 7.43 & 7.54 & 7.88 & 8.03 \\
\hline Southeast & 10.87 & 10.09 & 10.12 & 10.46 & 10.51 \\
\hline Southwest & 11.39 & 10.59 & 10.66 & 11.13 & 11.21 \\
\hline Rocky Mountain & 10.47 & 9.45 & 9.52 & 9.40 & 9.49 \\
\hline Far West & 9.47 & 7.98 & 8.33 & 8.02 & 8.37 \\
\hline
\end{tabular}

Source: Daniel Garnick, 1986.

The results are presented in Table 3. The numbers in the table correspond to the regions as follows:
1. New England
5. Southeast
2. Mideast
6. Southwest
3. Great Lakes
7. Rocky Mountain
4. Plains
8. Far West

The regions are separated into homogeneous subsets for the periods 1959-69, 1969-79 and 1979-84. Those whose growth rates do not differ significantly are listed in common subsets, regions not appearing in the same subset are distinctly different. The listings are in ascending order of rate of growth. 
Table 2

Two-Way Analysis of Variance of Total Personal Income and Earnings across Eight Regions of the United States and Three Time Periods, 1959-84

\begin{tabular}{lccc}
\hline \hline & \multicolumn{3}{c}{ F-ratios* } \\
\cline { 2 - 4 } \multicolumn{1}{c}{ Variable } & Region (R) & Time (T) & $\begin{array}{c}\text { Interaction } \\
\text { (RXT) }\end{array}$ \\
\hline Income & $25.97(7,69)$ & $154.02(2,69)$ & $4.96(14,69)$ \\
Earnings & $20.92(7,69)$ & $77.13(2,69)$ & $4.18(14,69)$ \\
Earnings excluding & & & \\
Farming & $21.65(7,69)$ & $74.27(2,69)$ & $4.85(14,69)$ \\
Manufacturing & $15.45(7,69)$ & $94.32(2,69)$ & $5.53(14,69)$ \\
Farming \& Mfg. & $16.40(7,69)$ & $93.32(2,69)$ & $5.56(14,69)$ \\
\hline
\end{tabular}

Numbers in parentheses are the degrees of freedom associated with testing the F-ratios for significance. All F-ratios are significant at the one percent confidence level or better.

Table 3

Ascending Order Rankings of Annual Rates of Growth of Total Personal Income and Earnings across Eight Regions of the United States and Three Time Periods, 1959-84*

\begin{tabular}{|c|c|c|c|}
\hline Item & $1959-69$ & $1969-79$ & $1979-84$ \\
\hline Total Income: & $\begin{array}{c}(324178) \\
(1786) \\
(7865)\end{array}$ & $\begin{array}{l}(2134) \\
(8576)\end{array}$ & 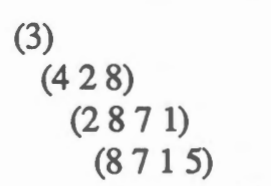 \\
\hline Earnings: & $\begin{array}{r}(243178) \\
\quad(431786) \\
\quad(7865)\end{array}$ & $\begin{array}{l}(2134) \\
\quad(485) \\
\quad(76)\end{array}$ & $\begin{array}{l}\text { (3) } \\
(42871) \\
(28715)\end{array}$ \\
\hline $\begin{array}{l}\text { Earnings } \\
\text { Excluding }\end{array}$ & & & \\
\hline Farming: & $\begin{array}{r}(234178) \\
(341786) \\
(7865)\end{array}$ & $\begin{array}{l}(2134) \\
\quad(485) \\
\quad(67)\end{array}$ & $\begin{array}{l}(34) \\
(428715)\end{array}$ \\
\hline $\begin{array}{l}\text { Earnings } \\
\text { Excluding } \\
\text { Manufacturing: }\end{array}$ & $\begin{array}{r}(4237186) \\
\quad(71865)\end{array}$ & $\begin{array}{l}(2134) \\
(485) \\
(857) \\
\quad(76)\end{array}$ & $\begin{array}{l}(348) \\
(4827) \\
\quad(516)\end{array}$ \\
\hline $\begin{array}{l}\text { Earnings } \\
\text { Excluding } \\
\text { Farming and } \\
\text { Manufacturing: }\end{array}$ & $\begin{array}{r}(4237168) \\
\quad(71685)\end{array}$ & $\begin{array}{r}(2134) \\
(485) \\
(857) \\
(576)\end{array}$ & $\begin{array}{l}(348) \\
\quad(4827) \\
\quad(516)\end{array}$ \\
\hline
\end{tabular}

"Numbers designate the regions as follows: 1) New England; 2) Mideast; 3) Great Lakes; 4) Plains; 5) Southeast; 6) Southwest; 7) Rocky Mountain; 8) Far West. 
Observing the classifications in Table 3 reveals that there are differences in regional groupings with respect to time and total income and earnings. Comparing the results across time periods reveals that a shift in the grouping occurs. For instance, during the period 1959-69, there was a great deal of overlapping in growth rates among the regions. For the period 1969-79, the distinction was more apparent with a bi-modal grouping comprised of permutations of regions 1,2,3 and 4 on one side, and regions 5, 6, 7 and 8 on the other side. For the period 1979-84, three general groupings are apparent: regions 1, 5 and 6 occupy one extreme; regions $2,3,4$ and 8 occupy the other extreme. Also, for each time period slight rearrangement of regions results when growth rates of total income and earnings, and of earnings excluding farming, manufacturing, and manufacturing and farming are compared.

These findings are in general agreement with those of Perlman (1982, p. 1) who points out that "over the long term four regions have experienced declining economic growth: the New England, Mideast, Great Lakes, and Plains regions; and four regions have experienced increasing economic growth: the Rocky Mountain, Southeast, Far West, and Southwest regions." Thus for the periods 1959 69 and 1969-79, note in Table 3 that regions 1, 2, 3 and 4 were grouped in the lowest growth category, while regions $5,6,7$ and 8 were in the highest growth category.

However, in the 1979-84 period, some noticeable reversals occurred: the New England economy recovered and the Mideast economy improved relatively. These results are evident from Table 3 where it can be observed that regions 1 and 2, representing New England and the Mideast, respectively, appear in the relatively high economic growth category.

Perlman (1982, p. 2) gave six explanations that may account for the shifts. Among these were: previous trends in output and populations; differential regional impacts of stagflation; effects of oil price changes; over-supply of steel and autos on one hand, and the strong demand for new products on the other; changes in population growth in non-metropolitan areas; and changes in state fiscal policies affecting industry location.

\section{Conclusions}

A main objective of this note was to explore the association of geographic regions, MSA size and time with rates of growth of total income and earnings. Three-way and two-way analysis of variance revealed that time was the most significant factor in explaining the differences in growth. The Newman-Keuls multiple comparison method was used to identify regions that had homogeneous rates of growth.

Various elements can contribute to differentces in rates of growth over time. Examples are: changes in the national industrial base; changes in technology; foreign competition; differences in the role of agriculture; and government policies. Other forces include the dispersion of industries, the redistribution of population, the establishment of new businesses related to new technologies and interregional variations in the supply of energy resources. The note did not address these issues. The intention was to present a profile of regional differences in income and earnings to supplement the extensive analyses provided by Garnick (1984, 1985, and 1986). Analysis of variance methods were deemed appropriate for this purpose.

\section{Notes}

The states which constitute the eight major geographic regions as classified by the Bureau of Economic Analysis are:

$\begin{array}{ccc}\text { 1. New England } & \text { 4. Plains } & \text { 6. Southwest } \\ \text { Connecticut } & \text { Iowa } & \text { Arizona } \\ \text { Maine } & \text { Kansas } & \text { New Mexico } \\ \text { Massachusetts } & \text { Minnesota } & \text { Oklahoma } \\ \text { New Hampshire } & \text { Missouri } & \text { Texas } \\ \text { Rhode Island } & \text { Nebraska } & \text { 7. Rocky Mountain } \\ \text { Vermont } & \text { North Dakota } & \text { Colorado } \\ \text { 2. Mideast } & \text { South Dakota } & \text { Idaho } \\ \text { Delaware } & \text { 5. Southeast } & \text { Montana } \\ \text { Maryland } & \text { Alabama } & \text { Utah } \\ \text { New Jersey } & \text { Arkansas } & \text { Wyoming } \\ \text { New York } & \text { Florida } & \text { 8. Far West } \\ \text { Pennsylvania } & \text { Georgia } & \text { California } \\ \text { 3. Great Lakes } & \text { Kentucky } & \text { Nevada } \\ \text { Illinois } & \text { Louisiana } & \text { Oregon } \\ \text { Indiana } & \text { Mississippi } & \text { Washington } \\ \text { Michigan } & \text { North Carolina } & \\ \text { Ohio } & \text { South Carolina } & \\ \text { Wisconsin } & \text { Tennessee } & \\ & \text { Virginia } & \\ & \text { West Virginia } & \\ & & \\ & \text { References } & \\ & & \end{array}$

Garnick, Daniel. "Shifting Balances in U.S. Metropolitan and Nonmetropolitan Area Growth." International Regional Science Review. 9:3(December 1984). 255-73.

"Patterns of Growth in Metropolitan and

Nonmetropolitan Areas: An Update." Survey of Current Business. (May 1985). 33-38.

"Local Area Economic Growth Patterns: A Comparison of the 1980 s and Previous Decades." Paper presented to National Academy of Sciences, July 1986.

Ostle, Bernard, and Linda L. Malone. Statistics in Research. Ames: Iowa State University Press, 1988.

Perlman, Mark. Patterns of Regional Economic Decline and Growth: The Past and What Has Been Happening Lately. Washington and London: American Enterpise Institute, 1982. 